\title{
Susceptibility of weed populations to glyphosate in banana plantations of the Department of Magdalena, Colombia
}

\author{
Irma Quintero-Pertuz ${ }^{1 *}$, Verónica Hoyos ${ }^{1}$, Eduino Carbonó-Delahoz ${ }^{2}$, and Guido Plaza ${ }^{3}$ \\ ${ }^{1}$ Universidad del Magdalena, Facultad de Ingeniería, C.P. 470004, Santa Marta, Colombia. \\ *Corresponding author (iquintero@unimagdalena.edu.co). \\ ${ }^{2}$ Universidad del Magdalena, Herbario UTMC, C.P. 470004, Santa Marta, Colombia. \\ ${ }^{3}$ Universidad Nacional de Colombia, Facultad de Ciencias Agrarias, A.A. 14490, Bogotá, Colombia.
}

Received: 31 October 2020; Accepted: 5 January 2021; doi:10.4067/S0718-58392021000200172

\begin{abstract}
The prevalence and deficient control with glyphosate in some weeds in banana (Musa $\times$ paradisiaca L.) plantations in the Department of Magdalena, Colombia, have been evidenced. The susceptibility to glyphosate of prevalent weeds in farms with more than $10 \mathrm{yr}$ of application of this herbicide was evaluated. Seeds and propagules of adult plants of five weedy species were collected from farms where deficient glyphosate control was observed (populations with possible resistance) and in areas not cultivated or free of herbicide use (susceptible populations). Under controlled conditions, seedlings obtained from 17 populations were treated with a commercial dose of glyphosate (1440 g acid equivalent [ae] ha-1 ${ }^{-1}$ or twice this dose $(2880 \mathrm{~g}$ ae ha-1 $)$. At $21 \mathrm{~d}$ after application, populations with a relative fresh weight and survival greater than $20 \%$ and visual control lower than $80 \%$ were categorized as resistant populations. To determine the resistance factor (RF) in the resistant populations, bioassays were performed with increasing doses of the herbicide $(0,720,1440,2880$, 5760, and $11520 \mathrm{~g}_{\text {ae ha }}{ }^{-1}$. Populations of Echinochloa colona (L.) Link and Melothria pendula L. were sensitive to both doses, while the populations of Commelina erecta L. and Syngonium podophyllum Schott were not controlled, confirming glyphosate-tolerant. Populations of Erigeron bonariensis L., from uncultivated areas was susceptible, while those from farms were resistant. Glyphosate-resistance was confirmed in two populations of E. bonariensis, with respective RF of 3.5 and 8.6. The repetitive application of glyphosate for weed control in the Magdalena banana farms has contributed to the prevalence of tolerant species and the appearance of herbicide-resistant weeds.
\end{abstract}

Key words: EPSPS, Erigeron bonariensis, Musa $\times$ paradisiaca, resistance, tolerance, weed control.

\section{INTRODUCTION}

Weed communities present temporal and spatial changes, are dynamic, and, as biological organisms, are in continuous evolution in response to climatic variations, crop cycles, edaphic factors, and especially the management of agroecosystems (Zimdahl, 2018). Their changes can be expressed as the appearance of new species within the community, the disappearance of some pre-existing species, the replacement of one species by another, or the evolution of biotypes with greater competitive ability in response to the selection pressures exerted by agricultural practices (Ghersa and Ferraro, 2013). The intensive use of herbicides in agriculture is one of the main causes of selection pressure due to their efficiency and selective control, they cause changes in the species in the area, including the resistance of weeds to herbicides (Mithila and Godar, 2013). 
The herbicide resistance (HR) defined by Weed Science Society of America (WSSA) as the "inherited ability of a plant to survive and reproduce following exposure to a dose of herbicide normally lethal to the wild-type", confers competitive advantages over susceptible individuals (Mithila and Godar, 2013). Additionally, by surviving, these resistant individuals will leave more offspring with the ability to withstand doses that are normally lethal, which together with their dissemination leads to failure in herbicide control (Fischer, 2012). However, these failures can also occur due to the tolerance of a species to the herbicide, which is defined by WSSA as the "inherent ability of a species to survive and reproduce after herbicide treatment". In this sense, it is important to differentiate between weed tolerance and resistance to herbicides (Qasem, 2013).

Currently, there are 514 unique cases (species $\times$ site of action) of HR weeds reported worldwide, of which 48 are resistant to glyphosate (Heap, 2020). The regular expansion of the area with the presence of glyphosate-resistant (GR) weeds and the rising number of resistant biotypes is a direct consequence of the massive increase in the use of this herbicide (Duke, 2018).

In Colombia, of 11 reports of HR biotypes (Heap, 2020), four are resistant to glyphosate: the species Eleusine indica and Conyza bonariensis (Erigeron bonariensis) in coffee plantations, Parthenium hysterophorus associated with fruit trees, and Chloris radiata in rice. Of the GR species reported across the world (Heap, 2020), six are common in banana (Musa $\times$ paradisiaca L.) plantations of Magdalena (Quintero-Pertúz et al., 2020): Amaranthus spinosus, C. bonariensis, Digitaria insularis, Echinochloa colona, E. indica, Leptochloa virgata, and Paspalum paniculatum. The latter has been reported in banana plantations in Costa Rica with more than $12 \mathrm{yr}$ of history of glyphosate application as the only method of weed control (Ramírez-Muñoz, 2016).

Although HR biotypes have not been reported in banana plantations in Colombia, some species have low susceptibility to glyphosate (at least at the most frequently used doses), which accounts for their prevalence in farms where herbicide applications have been made for more than $10 \mathrm{yr}$ as the only chemical control method (Quintero-Pertúz et al., 2020). According to agricultural engineers and field workers of the Magdalena banana zone, the species Commelina erecta, E. bonariensis, Syngonium podophyllum, Melothria pendula, Cyperus odoratus, Axonopus compressus, E. colona, E. indica, and Peperomia pellucida are becoming harder to control with glyphosate (Quintero-Pertúz et al., 2020). The loss of efficacy of an herbicide is the first factor to consider for the diagnosis of possible resistance, especially when a single herbicide or molecules with the same mode of action are used repeatedly and without alternative management tactics (Peterson et al., 2017).

Glyphosate is the only herbicide with a mechanism of action involving inhibition of the enzyme 5-enolpyruvylshikimate3-phosphate synthase (EPSPS), causing the interruption of the synthesis of essential amino acids, which leads to the death of sensitive plants in a matter of days. However, plants have developed multiple mechanisms to resist glyphosate, reduce its damage, and facilitate recovery after exposure (Zimdahl, 2018; Piasecki et al., 2019). These mechanisms can be at the site of action, such as mutations in the EPSPS gene that decrease the binding affinity of glyphosate or overexpression of EPSPS, which allows the plant to produce enough enzyme to maintain the synthesis of aromatic amino acids; and independent of the site of action, such as limited transport or absorption, isolation or vacuolar sequestration, or a rapid necrosis response, which causes the herbicide to not reach the target enzyme, resulting in very poor or ineffective control (Sammons and Gaines, 2014; Huang et al., 2019).

HR weeds are a cause of concern for many sectors of the agricultural community-farmers, councilors, consultants, researchers, and the chemical industry - because, in an extreme case of resistance, farmers could lose a chemical tool that has been essential for effectively controlling weeds (Pannell et al., 2016). Therefore, understanding the emergence of HR in weed populations in agricultural systems can help identify the problem earlier so that alternative control practices can be developed, which would help mitigate the evolution of resistant weeds (Fischer, 2012).

In response to field observations related to the loss of glyphosate sensitivity in some species associated with banana plantations of Magdalena, we evaluated glyphosate susceptibility in weeds to establish whether the prevalence of some weed species in farms where repetitive glyphosate control is performed is due to the evolution of HR populations. 


\section{MATERIALS AND METHODS}

During 2017 and 2018, seeds were collected from populations of the species Commelina erecta L., Melothria pendula L., Echinochloa colona (L.) Link, and Erigeron bonariensis L. and propagules of Syngonium podophyllum Schott from banana (Musa $\times$ paradisiaca L.) farms located in the banana zone of the Department of Magdalena, Colombia, where chemical control of weeds has been performed and poor control (populations with possible resistance) has been reported. As susceptible populations, planting material of the five species was also collected from areas not cultivated and/or free of herbicide use (Table 1).

Two types of bioassays were performed. A preliminary bioassay was run to detect resistant populations, and based on these results, a bioassay of dose-response curves was performed to confirm glyphosate resistance and quantify the resistance factor (RF) according to the method proposed by Burgos (2015).

\section{Bioassay for resistance detection}

The seeds of the species $C$. erecta and E. colona were pregerminated following the protocol standardized by Zabala et al. (2019) for E. colona seeds. The seeds were treated with $10 \% \mathrm{HCl}$ for $20 \mathrm{~min}$, then washed and placed in Petri dishes with $0.6 \%$ agar $(\mathrm{w} / \mathrm{v})$ and $0.2 \% \mathrm{KNO}_{3}$. The Petri dishes were kept in the incubation chamber for $8 \mathrm{~d}$. When the seedlings emitted the first leaf, they were transplanted into $10 \times 7 \times 8.5 \mathrm{~cm}$ pots that contained a substrate consisting of a mixture of soil, peat, and rice husk. The seeds of the species M. pendula and E. bonariensis and propagules of $3 \mathrm{~cm}$ (with at least two buds) of S. podophyllum were sown directly in the pots under controlled conditions. After transplantation and emergence of seedlings, thinning was performed to homogenize the growth state and ensure there were the same number of seedlings per pot for each species. Seedlings of 17 populations of the five species were treated at the 4-6 leaf growth stage with the recommended commercial dose (1440 $\mathrm{g}$ acid equivalent [ae] ha- $\left.{ }^{-1}\right)$ or twice this dose $\left(2880 \mathrm{~g} \mathrm{ae} \mathrm{ha}^{-1}\right)$ of glyphosate (isopropylammonium salt of N-(phosphonomethyl)glycine; Roundup 360 SL, Monsanto, Creve Coeur, Missouri, USA). The control treatment for each population was the absence of application (dose 0 ).

A completely randomized experimental design with five replicates was used. The experimental unit consisted of a pot with four seedlings for E. colona, M. pendula, and E. bonariensis and a pot with two seedlings for C. erecta and $S$. podophyllum. The herbicide applications were performed in a spray chamber equipped with flat fan nozzle (XR-8001, TeeJet Technologies) with a discharge of $213 \mathrm{~L} \mathrm{ha}^{-1}$, application rate $0.3 \mathrm{~m} \mathrm{~s}^{-1}$ and pressure $22 \mathrm{psi}$.

During the experiments, the conditions in the greenhouse were maintained between 28 to $36^{\circ} \mathrm{C}, 70 \%$ relative humidity, and a $12: 12 \mathrm{~h}$ photoperiod with a luminosity of 1500 to $1600 \mu \mathrm{mol} \mathrm{m}^{-1} \mathrm{~s}^{-1}$. Throughout the tests, a water sheet was maintained at a constant depth of $5 \mathrm{~cm}$ to keep the substrate saturated. Twenty-one days after application, relative fresh

Table 1. Sites of origin of the evaluated weed populations.

\begin{tabular}{|c|c|c|c|}
\hline Species & Population & Site of origin & Latitude-longitude \\
\hline \multirow[t]{3}{*}{ Commelina erecta $\mathrm{L}$. } & $\mathrm{CeFl}$ & Zona Bananera/Florida Farm & $10^{\circ} 54^{\prime} 04.6^{\prime \prime} \mathrm{N}, 74^{\circ} 11^{\prime} 14.8^{\prime \prime} \mathrm{W}$ \\
\hline & $\mathrm{CeBu}$ & Ciénaga/Burdeos Farm & $10^{\circ} 57^{\prime} 43.3^{\prime \prime} \mathrm{N}, 74^{\circ} 11^{\prime} 05.1^{\prime \prime} \mathrm{W}$ \\
\hline & CeUM* & Santa Marta/University of Magdalena Campus & $11^{\circ} 13^{\prime} 33.59^{\prime \prime} \mathrm{N}, 74^{\circ} 11^{\prime} 15.01^{\prime \prime} \mathrm{W}$ \\
\hline \multirow[t]{3}{*}{ Melothria pendula $\mathrm{L}$. } & $\mathrm{MpFl}$ & Zona Bananera/Florida Farm & $10^{\circ} 54^{\prime} 04.6^{\prime \prime} \mathrm{N}, 74^{\circ} 11^{\prime} 14.8^{\prime \prime} \mathrm{W}$ \\
\hline & $\mathrm{MpCh}$ & Zona Bananera/Chabela Farm & $10^{\circ} 54^{\prime} 29.5^{\prime \prime} \mathrm{N}, 74^{\circ} 11^{\prime} 12.7^{\prime \prime} \mathrm{W}$ \\
\hline & $\mathrm{MpBu}^{*}$ & Ciénaga/Burdeos Farm & $10^{\circ} 57^{\prime} 44.5^{\prime \prime} \mathrm{N}, 74^{\circ} 10^{\prime} 53.7^{\prime \prime} \mathrm{W}$ \\
\hline \multirow[t]{4}{*}{ Echinochloa colona (L.) Link } & $\mathrm{EcFl}$ & Zona Bananera/Florida Farm & $10^{\circ} 54^{\prime} 04.6^{\prime \prime} \mathrm{N}, 74^{\circ} 11^{\prime} 14.8^{\prime \prime} \mathrm{W}$ \\
\hline & $\mathrm{EcCh}$ & Zona Bananera/Chabela Farm & $10^{\circ} 54^{\prime} 21.3^{\prime \prime} \mathrm{N}, 74^{\circ} 11^{\prime} 11.9^{\prime \prime} \mathrm{W}$ \\
\hline & $\mathrm{EcBu}$ & Ciénaga/Burdeos Farm & $10^{\circ} 57^{\prime} 43.3^{\prime \prime} \mathrm{N}, 74^{\circ} 11^{\prime} 05.1^{\prime \prime} \mathrm{W}$ \\
\hline & ECUM* & Santa Marta/University of Magdalena Campus & $11^{\circ} 13^{\prime} 17.77^{\prime \prime} \mathrm{N}, 74^{\circ} 11^{\prime} 07.11^{\prime \prime} \mathrm{W}$ \\
\hline \multirow[t]{2}{*}{ Syngonium podophyllum Schott } & SpUII & Seville/La Unión II Farm & $10^{\circ} 47^{\prime} 33.1^{\prime \prime} \mathrm{N}, 74^{\circ} 08^{\prime} 58.8^{\prime \prime} \mathrm{W}$ \\
\hline & $\mathrm{SpBu}$ & Ciénaga/Burdeos Farm & $10^{\circ} 57^{\prime} 59.57^{\prime \prime} \mathrm{N}, 74^{\circ} 10^{\prime} 56.70^{\prime \prime} \mathrm{W}$ \\
\hline \multirow[t]{5}{*}{ Erigeron bonariensis L. } & EbEs & Aracataca/Esmeralda II Farm & $10^{\circ} 38^{\prime} 27.6^{\prime \prime} \mathrm{N}, 7^{\circ} 09^{\prime} 35.7^{\prime \prime} \mathrm{W}$ \\
\hline & EbUII & Seville/La Unión II Farm & $10^{\circ} 47^{\prime} 33.1^{\prime \prime} \mathrm{N}, 74^{\circ} 08^{\prime} 58.8^{\prime \prime} \mathrm{W}$ \\
\hline & $\mathrm{EbCh}$ & Zona Bananera/Chabela Farm & $10^{\circ} 54^{\prime} 33.8^{\prime \prime} \mathrm{N}, 74^{\circ} 11^{\prime} 18.3^{\prime \prime} \mathrm{W}$ \\
\hline & EbSR & Zona Bananera/Santa Rita Farm & $10^{\circ} 45^{\prime} 03.66^{\prime \prime} \mathrm{N}, 74^{\circ} 07^{\prime} 10.5^{\prime \prime} \mathrm{W}$ \\
\hline & EbSL* & Santa Marta/Vía a San Lorenzo & $11^{\circ} 06^{\prime} 24.9^{\prime \prime} \mathrm{N}, 75^{\circ} 04^{\prime} 13^{\prime \prime} \mathrm{W}$ \\
\hline
\end{tabular}

*Susceptible control populations. 
weight (\%), survival (\%), and visual control (\%) were assessed. Relative fresh weight was estimated by taking into account the fresh weight of the herbicide-treated plants and the average fresh weight of the controls (dose 0), expressed as a percentage. To evaluate the control efficacy, visual observation was performed using a subjective weed control scale from 0 to 100 , where 0 corresponded to $0 \%$ control and 100 to $100 \%$ weed control, according to the symptoms observed in comparison with the control without herbicide. Survival was measured considering the number of live plants with active growth after treatment in relation to the number of treated plants counted just before application and is expressed as percentage. The populations were categorized as susceptible (S) or resistant $(\mathrm{R})$ independently for each of these three variables, according to the classification criteria described by Zabala et al. (2019). Populations with relative weight and survival greater than $20 \%$ and visual control less than $80 \%$, evaluated at the commercial dose of the herbicide, were categorized as resistant $(\mathrm{R})$.

\section{Bioassay of dose-response curves}

Taking into account the results obtained in the previous bioassay, three populations of E. bonariensis were selected: EbSR and EbCh (R) and EbSL (S). Increasing doses of glyphosate used: 0, 1X, 2X, 4X, and 8X, where X corresponds to the recommended commercial dose $\left(1440 \mathrm{~g}_{\text {ae }} \mathrm{ha}^{-1}\right)$. Population $\mathrm{S}$ was treated from the $\mathrm{X} / 2$ dose to the $2 \mathrm{X}$ dose. The treatments were chosen under a completely randomized design with four replicates; the test was repeated over time for validation. The applications, growth conditions, and variables (fresh weight and survival) were evaluated as in the previous bioassay.

\section{Analysis of data}

The dose-response curves were drawn by means of a nonlinear regression model using the log-logistic equation of three parameters (Ritz et al., 2015): $\mathrm{Y}=\left[\mathrm{d} /\left(1+(\mathrm{x} / \mathrm{g})^{\wedge} \mathrm{b}\right)\right]$, where $\mathrm{Y}$ is the percentage of growth, $\mathrm{d}$ is the average response when the herbicide dose approaches zero (upper limit), $\mathrm{b}$ is the slope of the line when there is a 50\% reduction in growth $\left(\mathrm{GR}_{50}\right)$ or survival $\left(\mathrm{LD}_{50}\right)$, $\mathrm{g}$ is the herbicide rate inhibiting plant growth by $50 \%\left(\mathrm{GR}_{50}\right)$ or the dose required to control $50 \%$ of the plants $\left(\mathrm{LD}_{50}\right)$, and $\mathrm{x}$ (independent variable) corresponds to the dose of glyphosate. The regression parameters of the susceptible and resistant populations were obtained by RStudio 1.0.143 with the "drc" package (Ritz et al., 2015). The $\mathrm{RF}$ was calculated by dividing the $\mathrm{GR}_{50}$ or $\mathrm{LD}_{50}$ value of an $\mathrm{R}$ biotype by the $\mathrm{GR}_{50}$ or $\mathrm{LD}_{50}$ of an $\mathrm{S}$ biotype. An $\mathrm{RF}$ greater than 2 (statistically, based on your confidence interval) was taken as confirmation that the analyzed populations were resistant to herbicide (Heap, 2020).

\section{RESULTS}

\section{Detection of glyphosate-resistance}

The populations of E.colona and M.pendula (including those suspected of resistance) were efficiently controlled with the recommended commercial dose $\left(1440 \mathrm{~g}\right.$ ae $\left.\mathrm{ha}^{-1}\right)$. In both species, the relative weight and survival were lower than $20 \%$, and the control percentages were higher than $80 \%$ (Figure 1), values that categorized them as S (Table 2).

The three populations of $C$. erecta, including the susceptible population $\left(\mathrm{CeUM}^{*}\right)$, were not controlled efficiently, given that they showed average relative weight between 5\% and 20\%, survival above $80 \%$, and visual control of $80 \%$ with the $2 \mathrm{X}$ dose (Figure 1). Although these values categorized the populations as $\mathrm{R}$ (Table 2), the ineffectiveness in the control of the CeUM* population (susceptible population) confirmed that the species was not controlled with glyphosate because it presented natural tolerance to the herbicide (Panigo et al., 2012).

A similar response was observed in the two populations of S. podophyllum (SpUII and SpBu*), which showed an average relative weight greater than $20 \%$, survival of $100 \%$, and control less than $10 \%$ with the $2 \mathrm{X}$ dose (Figure 1). Therefore, they were categorized as $\mathrm{R}$ (Table 2). As in C. erecta, the ineffectiveness of glyphosate in the susceptible population of S. podophyllum ( $\mathrm{SpBu}^{*}$ ) confirmed that the species had natural tolerance to the herbicide.

Of the E. bonariensis populations, EbSL* was $100 \%$ controlled by the lowest dose of glyphosate, confirming its susceptibility (Figure 2). On the other hand, EbCh, EbSR, EbUII, and EbEs from banana farms were not efficiently controlled with the glyphosate doses evaluated. These populations presented average values of relative weight that varied between 5\% to 30\%, survival greater than 20\%, and visual control less than $80 \%$ (Figure 2A). Pooling the results of the three variables allowed us to categorize them as R populations (Table 2). 
Figure 1. Effect of glyphosate application at the commercial dose $\left(1 \mathrm{X}=1440 \mathrm{~g}^{\mathrm{ae} \mathrm{ha}} \mathrm{h}^{-1}\right)$ or double dose $(2 \mathrm{X})$ on the fresh weight (A), survival (B), and visual control (C) of 17 populations of five weed species in banana fields in the Department of Magdalena, Colombia.
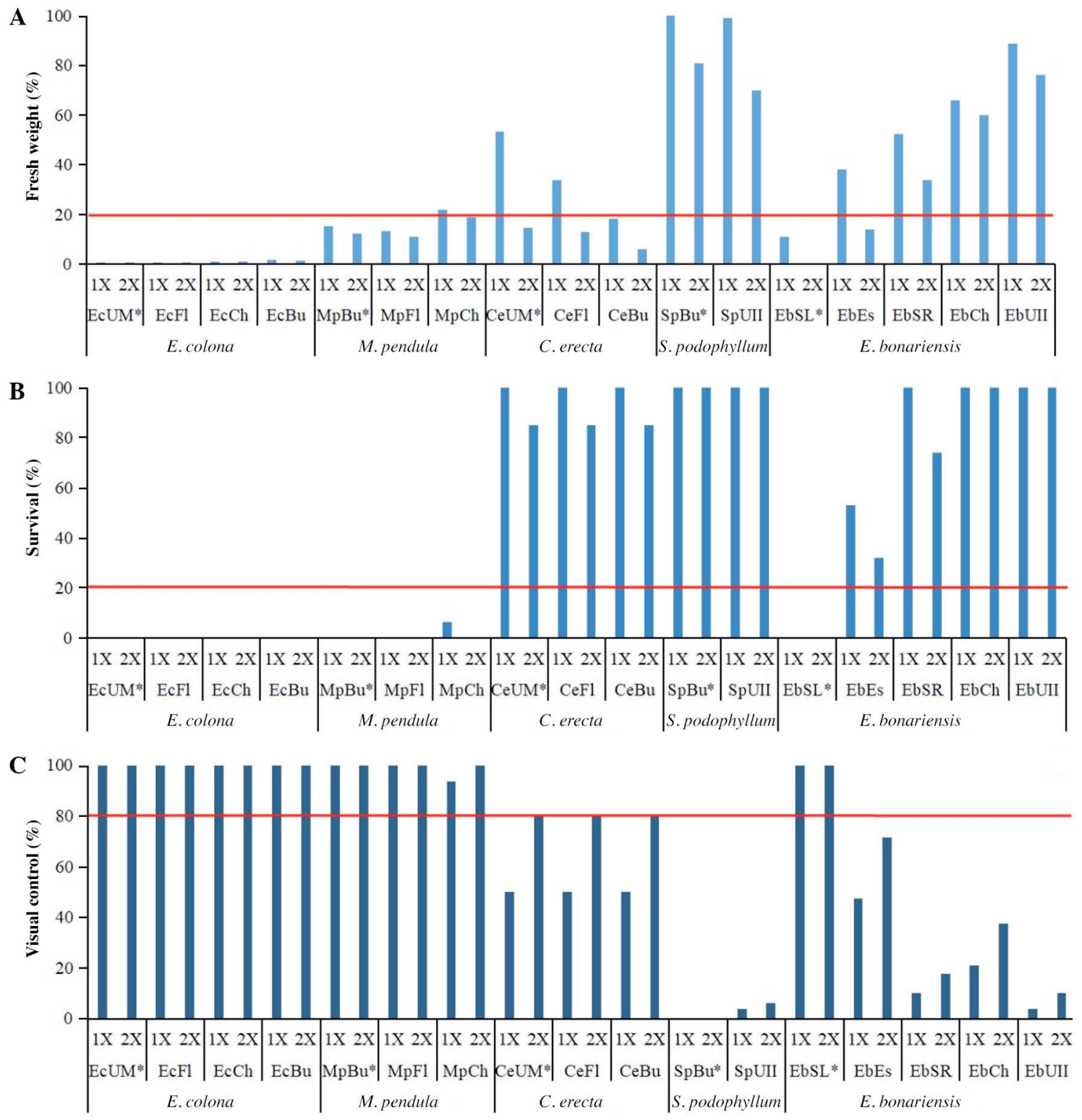

The horizontal line at $20 \%$ in A and B and at $80 \%$ in C represents the discriminatory limit between resistant and susceptible populations when plants were treated at the $1 \mathrm{X}$ dose.

Weed species: Echinochloa colona, Melothria pendula, Commelina erecta, Syngonium podophyllum, Erigeron bonariensis.

\section{Confirmation of glyphosate-resistance}

The dose-response curves confirmed the evolution of resistance in the E. bonariensis populations evaluated (Table 3). The dose of glyphosate necessary to reduce fresh weight of the EbSL population to $50 \%\left(\mathrm{GR}_{50}\right)$ was $729.41 \mathrm{~g}^{a e} \mathrm{ha}^{-1}$, lower than the recommended commercial dose $\left(1440 \mathrm{~g}\right.$ ae ha-1), confirming the susceptibility of the population. The $\mathrm{GR}_{50}$ values for the EbCh and EbSR populations were 2541.17 and $6264.07 \mathrm{~g} \mathrm{ae} \mathrm{ha}^{-1}$ glyphosate, respectively (Table 3, Figure 1A). The RFs calculated based on the $\mathrm{GR}_{50}$ criterion showed that 3.5 and 8.6 times the dose for the susceptible population would be required to reduce the growth of the EbCh and EbSR populations by 50\%, respectively. RF values between 2 and 10 suggest that the resistance is moderate (Heap, 2020). 
Table 2. Glyphosate resistance category of 17 populations of four weed species associated with banana plantations in the Department of Magdalena, Colombia.

\begin{tabular}{|c|c|c|c|c|c|c|c|c|}
\hline \multirow[b]{2}{*}{ Species } & \multirow[b]{2}{*}{ Population } & \multicolumn{2}{|c|}{$\begin{array}{l}\text { Relative fresh } \\
\text { weight }\end{array}$} & \multicolumn{2}{|c|}{ Survival } & \multicolumn{2}{|c|}{ Visual control } & \multirow{2}{*}{$\begin{array}{l}\text { General } \\
\text { category** }\end{array}$} \\
\hline & & $1 \mathrm{X}$ & $2 X$ & $1 \mathrm{X}$ & $2 \mathrm{X}$ & $1 \mathrm{X}$ & $2 X$ & \\
\hline \multirow[t]{4}{*}{ Echinochloa colona } & EcUM* & S & S & $S$ & $S$ & $S$ & $S$ & S \\
\hline & EcFl & S & S & S & S & S & S & S \\
\hline & $\mathrm{EcCh}$ & S & S & S & S & S & S & S \\
\hline & $\mathrm{EcBu}$ & $\mathrm{S}$ & $\mathrm{S}$ & S & S & $\mathrm{S}$ & S & S \\
\hline \multirow[t]{3}{*}{ Melothria pendula } & $\mathrm{MpBu}^{*}$ & SR & SR & $S$ & S & $\mathrm{S}$ & $S$ & S \\
\hline & $\mathrm{MpFl}$ & SR & SR & $\mathrm{S}$ & S & $\mathrm{S}$ & S & $\mathrm{S}$ \\
\hline & $\mathrm{MpCh}$ & $\mathrm{R}$ & SR & SR & $\mathrm{S}$ & SR & $\mathrm{S}$ & SR \\
\hline \multirow[t]{3}{*}{ Commelina erecta } & CeUM* & $\mathrm{R}$ & SR & $\mathrm{RR}$ & $\mathrm{RR}$ & $\mathrm{R}$ & $\mathrm{RR}$ & $\mathrm{RR}$ \\
\hline & $\mathrm{CeFl}$ & $\mathrm{R}$ & SR & $\mathrm{RR}$ & $\mathrm{RR}$ & $\mathrm{R}$ & $\mathrm{RR}$ & $\mathrm{RR}$ \\
\hline & $\mathrm{CeBu}$ & $\mathrm{R}$ & SR & RR & $\mathrm{RR}$ & $\mathrm{R}$ & $\mathrm{RR}$ & RR \\
\hline \multirow[t]{2}{*}{ Syngonium podophyllum } & $\mathrm{SpBu}$ & $\mathrm{RR}$ & $\mathrm{RR}$ & RR & RR & RR & $\mathrm{RR}$ & $\mathrm{RR}$ \\
\hline & SpUII & $\mathrm{RR}$ & $\mathrm{RR}$ & RR & $\mathrm{RR}$ & RR & $\mathrm{RR}$ & $\mathrm{RR}$ \\
\hline \multirow[t]{5}{*}{ Erigeron bonariensis } & EbSL* & SR & $\mathrm{S}$ & $\mathrm{S}$ & $\mathrm{S}$ & $\mathrm{S}$ & $\mathrm{S}$ & $\mathrm{S}$ \\
\hline & EbEs & $\mathrm{RR}$ & $\mathrm{R}$ & RR & RR & RR & $\mathrm{RR}$ & RR \\
\hline & EbSR & $\mathrm{RR}$ & RR & RR & RR & RR & $\mathrm{RR}$ & $\mathrm{RR}$ \\
\hline & $\mathrm{EbCh}$ & $\mathrm{RR}$ & $\mathrm{RR}$ & $\mathrm{RR}$ & $\mathrm{RR}$ & $\mathrm{RR}$ & $\mathrm{RR}$ & $\mathrm{RR}$ \\
\hline & EbUII & $\mathrm{RR}$ & RR & RR & RR & RR & $\mathrm{RR}$ & RR \\
\hline
\end{tabular}

*Control population, evaluated as susceptible, from non-cultivated areas or free of herbicide use.

**The general category of resistance was estimated from the nature of the three variables.

S and SR: Susceptible, R and RR: resistant. The populations with relative fresh weight and survival greater than $20 \%$ and visual control less than $80 \%$ were categorized as $\mathrm{R}$ when evaluated at the commercial dose of herbicide (1X) and as RR when evaluated at the $2 \mathrm{X}$ dose $\left(\mathrm{X}=1440 \mathrm{~g}\right.$ ae ha- $\left.{ }^{-1}\right)$.

Figure 2. Log-logistic model curves of resistant (EbCh and EbSR) and susceptible (EbSL) populations of Erigeron bonariensis to different doses of glyphosate $21 \mathrm{~d}$ after application; percentage of fresh weight reduction (A) and percentage of survival (B).
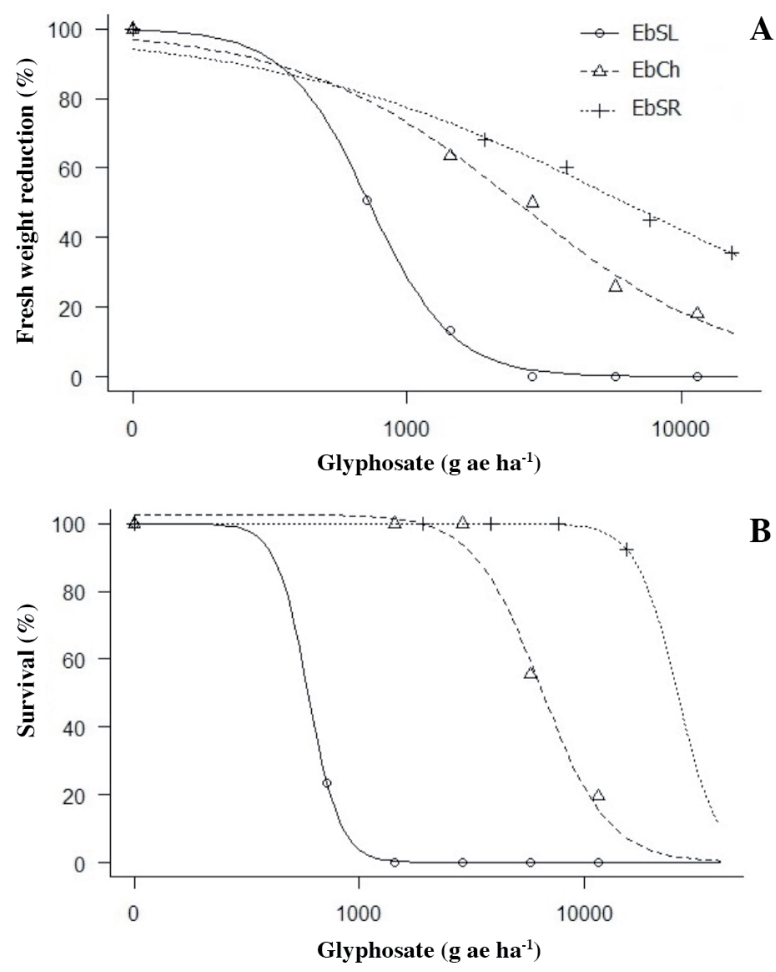
Table 3. Parameters estimated from the logistic analysis and values of the growth reduction $\left(G_{\mathbf{G}_{00}}\right)$ and mean lethal dose $\left(\mathrm{LD}_{50}\right)$ in three populations of Erigeron bonariensis.

\begin{tabular}{|c|c|c|c|c|c|c|}
\hline & & & $\mathrm{GR}_{50}$ & $\mathrm{GR}_{90}$ & & \\
\hline Populations & $\mathrm{b}$ & $\mathrm{d}$ & g ae ha-1 & $\mathrm{g}$ ae ha-1 & $\mathrm{p}$ & RF \\
\hline EbSL* & 2.87 & 100 & 729.41 & 1568.35 & $<0.0001$ & \\
\hline $\mathrm{EbCh}$ & 1.076 & 100 & 2545.17 & 19599.70 & $<0.0001$ & 3.48 \\
\hline \multirow[t]{2}{*}{ EbSR } & -6.726 & 100 & 6264.07 & 164272.00 & $<0.0001$ & 8.58 \\
\hline & & & $\mathrm{LD}_{50}$ & $\mathrm{LD}_{90}$ & & \\
\hline Populations & $\mathrm{b}$ & $\mathrm{d}$ & $\mathrm{g}$ ae ha- & $\mathrm{g}$ ae ha- ${ }^{-1}$ & $\mathrm{p}$ & $\mathrm{RF}$ \\
\hline EbSL* & 6.191 & 100 & 594.09 & & $<0.0001$ & \\
\hline $\mathrm{EbCh}$ & 2.784 & 100 & 6413.00 & - & $<0.0001$ & 10.79 \\
\hline EbSR & 4.549 & 100 & $>11520.00$ & - & - & $>19.40$ \\
\hline
\end{tabular}

*Susceptible population from areas free of glyphosate application.

b: Slope; d: average response; RF: resistance factor.

Regarding survival, the dose required to control $50 \%$ of the plants $\left(\mathrm{LD}_{50}\right)$ was $594.09 \mathrm{~g}^{\mathrm{a}} \mathrm{ha}^{-1}$ for the $\mathrm{S}$ population, approximately half of the commercial dose. At the highest dose evaluated $\left(11520 \mathrm{~g}\right.$ ae ha- $\left.{ }^{-1}\right)$, the EbSR population showed a survival rate greater than $90 \%$ (Table 3, Figure 1B), and it was not possible to estimate $\mathrm{LD}_{50}$ for this population. The $\mathrm{LD}_{50}$ for the EbCh population was $6413 \mathrm{~g}$ ae ha-1 10.8 times higher than that of $\mathrm{S}$ (Table 3, Figure 1B). Their $\mathrm{LD}_{50}$-based $\mathrm{RF}$ values greater than 10 suggest that resistance is medium in both populations (Heap, 2020).

\section{DISCUSSION}

The efficient control of the populations of E. colona and $M$. pendula with the recommended commercial dose of glyphosate confirms their susceptibility to the herbicide. Therefore, the reported field control failures may be due to errors in application (dose used, methods and time of application, among others). It was evident from our observation of the study area that herbicide is applied when most of the weed populations are in a flowering or reproductive state, and in some cases, the doses used are lower than the recommended by the product label (information collected through surveys conducted during field sampling).

According to Kleinman et al. (2015), applying glyphosate to plants too advanced in their cycle leads to control failure, given that at later stages of development, susceptibility to herbicide decreases. Although low doses of an herbicide can efficiently control susceptible populations, they could also allow the survival of individuals possessing some partialresistance genes (Fischer, 2012). These individuals could eventually exchange and accumulate resistance genes that may be pre-existing in the population (genetic variation) or may be induced by stress due to the sublethal effect of the herbicide (Gressel, 2010). Over time, the level of resistance can increase, and its frequency will be increased by the selection pressure of the herbicide; therefore, the application of the maximum recommended dose of the herbicide should be adhered to in the management of weeds and avoid too low application rates from the beginning (Gressel, 2010; Mithila and Godar, 2013). These considerations should be taken into account in the banana plantations of the region with a prevalence of $E$. colona, since it has reported populations resistant to glyphosate (Heap, 2020). According to Werth et al. (2013), the high dependence on glyphosate for weed control in crop fields increases the risk of shifts to glyphosate-tolerant species and the evolution of glyphosate-resistant weeds, which leads to the prevalence or increase of their dominance in systems based on the use of this herbicide.

The populations of $C$. erecta were not controlled efficiently even with the double of the dose of the herbicide, results are consistent with the findings of Panigo et al. (2012), who found this species was tolerant to doses of 900-1920 $\mathrm{g}_{\text {ae }} \mathrm{ha}^{-1}$ glyphosate. According to Nisensohn et al. (2011), the tolerance to glyphosate of $C$. erecta varies with the stage of development, so this is an important aspect to consider when applying the herbicide. Additionally, the ability of the genus Commelina to propagate by seeds and vegetatively through rhizomes and cuttings, as well as the reserve starch in its stem, may be related to its tolerance to glyphosate, since these characteristics provide a greater likelihood of recovery after herbicide application (Panigo et al., 2012). 
Poor control of the two populations of S. podophyllum, even with the double of dose of glyphosate, indicates a natural tolerance of the species to the herbicide. Although it is reportedly difficult to control in banana crops with intensive applications of glyphosate in Costa Rica (Brenes-Prendas et al., 2012) and Colombia (Quintero-Pertúz et al., 2020), $S$. podophyllum had not been reported as tolerant to herbicides, so these results are the first to show the tolerance of the species to glyphosate. The morphological and anatomical characteristics of leaves of S. podophyllum, such as the presence of stomata on both surfaces, a parenchyma with a multitude of aerial channels, and their content of starch grains and calcium oxalate crystals (Sipos and Trif, 2009), histochemical characteristics that reduce the penetration and/ or translocation of the herbicide and could be associated with glyphosate tolerance, as has been verified in other species with natural tolerance to the herbicide (Galon et al., 2013). The ability to reproduce both sexually and vegetatively and to present morphological variations during its growth cycle contribute to the propagation, adaptation, and rapid growth of the species in banana plantations (Brenes-Prendas et al., 2012). These morphological, structural, and physiological factors could also confer adaptive advantages of a population weed that would allow it to survive and increase in systems with intensive use of glyphosate (Dellaferrera et al., 2015). However, studies on the specific morphological and physiological characteristics that might confer glyphosate tolerance to $S$. podophyllum are necessary.

Herbicide tolerance is evidenced when the continuous use of the same molecule and dose selects one or more species that are naturally tolerant to that herbicide/dose within the community; these species would tend to predominate in farms where frequent treatments with the same active ingredient have been carried out (Werth et al., 2013). This would explain the prevalence of C. erecta and S. podophyllum in the banana plantations evaluated.

The results obtained in the bioassays for the detection of glyphosate resistance in E. bonariensis populations show, for the first time, the presence of HR populations in banana crops in Colombia, and this is the second case of glyphosate resistance for this species in the country. The first case was reported in 2006 in coffee crops (Heap, 2020) where there had been a high frequency of glyphosate application for more than $10 \mathrm{yr}$. However, the resistance factor in these biotypes was not estimated.

The RFs estimated in this study indicate that 3.5 and 8.6 times more herbicide is needed in R populations than $\mathrm{S}$ populations to cause a $50 \%$ reduction in fresh weight $\left(\mathrm{GR}_{50}\right)$. According to these values, it is necessary to apply between

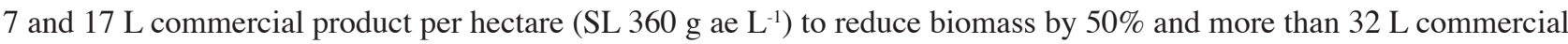
product ha ${ }^{-1}$ (highest evaluated dose) to reach a 90\% control, values that exceed the recommended dose of use for any active ingredient in different crops. These results are in line with Puricelli et al. (2015), Kleinman et al. (2015), and Koetz and Asaduzzaman (2020), who reported RF values of 3.5 to 7.0 and requirements of 3 to 4 times the susceptiblepopulation dose of glyphosate to achieve a $90 \%$ control in resistant populations of $E$. bonariensis.

The extensive use of herbicides has led to numerous HR populations of Conyza spp. (Erigeron spp.) (Matzrafi et al., 2015). Several factors can influence the dynamics of this process, such as genetic factors, the physiology of the weed species, herbicide and target site properties, herbicide dose, and application yield (Menalled et al., 2016). According to Fischer (2012), the evolution of HR in a population is accelerated when the initial frequency of resistant biotypes is high, when it is inherited through a single gene that is dominant in a species of cross-fertilization, when the species is very susceptible to herbicide, when it kills the plant through a single mechanism, or when it is inactivated by a very common process in plants.

Research on the mechanism of glyphosate resistance of E. bonariensis has shown that this is not the result of EPSPS mutations or overexpression (González-Torralva et al., 2014; Hereward et al., 2018; Piasecki et al., 2019) but is unrelated to the active site. It is due to the accumulation and sequestration of glyphosate subcellularly, probably in vacuoles, which prevents the herbicide from being transported to other sites of the plant (González-Torralva et al., 2014; Amaro-Blanco et al., 2018; Hereward et al., 2018). According to Piasecki et al. (2019), the non-active-site-related glyphosate resistance in E. bonariensis is mediated by a group of genes that can participate (individually or together) in the metabolism, transport, and degradation of the herbicide in such a way that they can rescue plants resistant to irreversible damage after glyphosate treatment; gene expression varies between biotypes in response to treatment with glyphosate and depends on the time of exposure to the herbicide. In this regard, Anagnostopoulos et al. (2020), found differences in the metabolism of biotypes of three species of Conyza to two herbicides, pointing out that $C$. bonariensis (E. bonariensis) has a greater capacity to transform glyphosate into non-toxic metabolites. Further studies are needed to determine the mechanisms of resistance in E. bonariensis populations associated with banana plantations in Magdalena. 
The prevalence or growth of populations of some weeds in crop fields can also be related to their ability to produce a high number of seeds, and because glyphosate does not have residual action, there is a greater opportunity for growth of new populations from the soil seed bank (Green, 2010). The existence of seeds that manage to escape glyphosate control, added to the little disturbance of the soil of adult banana plantations, plus the high percentage of viability and different degrees of dormancy of the seeds, leads to an increase in the frequency and density of some weeds, as verified by the populations of C. erecta (Nisensohn et al., 2011), E. bonariensis (Metzler et al., 2013), and E. colona (Picapietra et al., 2020). The rapid colonization of $E$. bonariensis populations can be attributed to the dispersion of its seeds, facilitated by wind and water, which increases under favorable conditions of humidity and temperature (Green, 2010), conditions that occur in the banana fields of the region. According to Green (2010), seed dispersal contributes to the propagation of GR weed populations. In this sense, efficient monitoring and control of these populations in banana systems is essential to mitigate the evolution of resistance.

\section{CONCLUSIONS}

The populations of Melothria pendula and Echinochloa colona were susceptible to glyphosate, which allows us to infer that the failures in the control and prevalence of populations of these species in some farms can be due to errors in application. Commelina erecta and Syngonium podophyllum were glyphosate-tolerant, a characteristic that favors the competitive ability of these species and explains the difficulty controlling them and their prevalence in plantations. Glyphosate resistance was confirmed in Erigeron bonariensis populations from banana farms, which shows that the prevalence of this species in these farms is due to the evolution of herbicide-resistant populations.

The prevalence of weeds tolerant or resistant to glyphosate in banana farms where the herbicide has been applied continuously for at least $10 \mathrm{yr}$ as the only control method shows that these species have experienced selection pressure, which has led to the evolution of biotypes with greater competitive ability. These findings indicate that weed management based on a single method is not efficient.

\section{ACKNOWLEDGEMENTS}

We thank AUGURA, especially engineer Helena Bornacelly, for logistical support for access to farms. We thank Edwin Ordóñez and Gregory Mendoza for their support and accompaniment in the field collection and on data collection missions.

\section{REFERENCES}

Anagnostopoulos, C., Stasinopoulou, P., Kanatas, P., and Travlos, I. 2020. Differences in metabolism of three Conyza species to herbicides glyphosate and triclopyr revealed by LC-MSMS. Chilean Journal of Agricultural Research 80:100-107. doi:10.4067/S0718-58392020000100100.

Amaro-Blanco, I., Fernández, P.T., Osuna, M.D, Bastida, F., and De Prado, R. 2018. Mechanisms of glyphosate resistance and response to alternative herbicide-based management in populations of the three Conyza species introduced in southern Spain. Pest Management Science 74:1925-1937.

Brenes-Prendas, S., Wang-Wong, A., y Agüero-Alvarado, R. 2012. Fitopatógenos asociados a Dieffenbachia oerstedii y Syngonium podophyllum en plantaciones de banano en Costa Rica. Agronomía Mesoamericana 23(1):201-206.

Burgos, N. 2015. Whole-plant and seed bioassays for resistance confirmation. Weed Science 63(SP1):152-165. doi:10.1614/WS-D-14-00019.1.

Dellaferrera, I.,Panigo, E., Gonzalez-Torralba, F., De Prado, R., Christoffoleti, P., y Perreta, M. 2015. Características estructurales y fisiológicas de Petunia axillaris relacionadas con su baja sensibilidad a glifosato. Planta Daninha 33(3):451-462.

Duke, S.O. 2018. The history and current status of glyphosate. Pest Management Science 74:1027-1034. doi:10.1002/ps.4652.

Fischer, A. 2012. Resistencia a herbicidas: mecanismos y mitigación. Revista Especial Maleza. p. 13-19. Asociación Argentina de Productores en Siembra Directa (Aapresid), Buenos Aires, Argentina. Available at http://aapresid.org.ar/wp-content/ uploads/sites/3/2013/02/REMSD12_002.pdf (accessed 12 November 2019).

Galon, L., Ferreira, E.A., Aspiazú, I., Concenço, G., Silva, A.F., Silva, A.A., et al. 2013. Glyphosate translocation in herbicide tolerant plants. Planta Daninha 31(3):193-201.

Ghersa, C.M., y Ferraro, D.O. 2013. Algunos aspectos acerca de la aparición de resistencia a herbicidas en poblaciones de malezas. Revista Especial Maleza. p. 21-24. Asociación Argentina de Productores en Siembra Directa (Aapresid), Buenos Aires, Argentina. Available at https://ri.conicet.gov.ar/bitstream/handle/11336/97082/CONICET_Digital_Nro.dcef65dc6e89-4730-b457-f115bcfa9406_A.pdf?sequence=2\&isAllowed=y (accessed 19 November 2019). 
González-Torralva, F., Gil-Humanes, J., Barro, F., Domínguez-Valenzuela, J., and De Prado, R. 2014. First evidence for a target site mutation in the EPSPS2 gene in glyphosate-resistant Sumatran fleabane from citrus orchards. Agronomy Sustainable Development 34:553-560.

Green, T.D. 2010. The ecology of fleabane (Conyza spp.) Doctoral thesis. School of Environmental and Rural Science, Faculty of Arts and Sciences, University of New England, Armidale, New South Wales, Australia.

Gressel, J. 2010. Low pesticide rates may hasten the evolution of resistance by increasing mutation frequencies. Pest Management Science 67:253-257

Heap, I. 2020. The International Herbicide-Resistant Weed Database. Online. Available at http://www.weedscience.org (accessed 24 June 2020)

Hereward, J.P., Werth, J.A., Thornby, D.F., Keenan, M., Chauhan, B.S., and Walter, G.H. 2018. Gene expression in response to glyphosate treatment in fleabane (Conyza bonariensis)-glyphosate death response and candidate resistance genes. Pest Management Science 74(10):2346-2355.

Huang, Z., Liu, Y., Zhang, CH., Jiang, C., Huang, H., and Wei, S. 2019. Molecular basis of natural tolerance to glyphosate in Convolvulus arvensis. Scientific Reports 9:8133.

Kleinman, Z., Ben-Ami, G., and Rubin, B. 2015. From sensitivity to resistance - factors affecting the response of Conyza spp. to glyphosate. Pest Management Science 72(9):1681-1688.

Koetz, E., and Asaduzzaman, M. 2020. Susceptibility of fleabane (Conyza bonariensis) biotypes to glyphosate in northern cotton farming systems of Australia. Journal of Research in Weed Science 3(2):133-144.

Matzrafi, M., Lazar, T.W., Sibony, M., and Rubin, B. 2015. Conyza species: distribution and evolution of multiple target-site herbicide resistances. Planta 242(1):259-267.

Menalled, F.D., Peterson, R.K., Smith, R.G., Curran, W.S., Paez, D.J., and Maxwell, B.D. 2016. The eco-evolutionary imperative: revisiting weed management in the midst of an herbicide resistance crisis. Sustainability 8(12):1297.

Metzler, M., Puricelli, E., y Papa, J.C. 2013. Manejo y control de rama negra. Asociación Argentina de Productores en Siembra Directa (Aapresid), Buenos Aires, Argentina. Available at https://www.aapresid.org.ar/wp-content/uploads/sites/3/2013/10/ Metzler.-Manejo-y-control-de-Rama-negra.pdf (accessed 19 July 2019).

Mithila, J., and Godar, A.S. 2013. Understanding genetics of herbicide resistance in weeds: Implications for weed management. Advances in Crop Science and Technology 1:115.

Nisensohn, L., Tuesca, D.H., y Vitta, J.I. 2011. Características reproductivas de Commelina erecta L. asociadas con su propagación en sistemas agrícolas. Agriscientia 28:51-60.

Panigo, E.S., Dellaferrera, I.M., Acosta, J.M., Bender, A.G., Garetto, J., and Perreta, M.G. 2012. Glyphosate-induced structural variations in Commelina erecta L. (Commelinaceae). Ecotoxicology and Environmental Safety 76:135-142.

Pannell, D., Tillie, P., Rodríguez, E., Ervin, D., and Frisvold, G. 2016. Herbicide resistance: Economic and environmental challenges. AgBioForum 19(2):136-155.

Peterson, M., Collavo, A., Ovejero, R., Shivrain, V., and Walsh, M. 2017. The challenge of herbicide resistance around the world: A current summary. Pest Management Science 74(10):2246-2259.

Piasecki, C., Yang, Y., Benemann, D.P., Kremer, F.S., Galli, V., Millwood, R.J., et al. 2019. Transcriptomic analysis identifies new non-target site glyphosate-resistance genes in Conyza bonariensis. Plants 8(6):157.

Picapietra, G., González-Andújar, J.L., and Acciaresi, H.A. 2020. Predicting junglerice (Echinochloa colona L.) emergence as a function of thermal time in the humid pampas of Argentina. International Journal of Pest Management, doi:10.1080/09670874.2020.1778811.

Puricelli, E., Faccini, D., Metzler, M., and Torres P. 2015. Differential susceptibility of Conyza bonariensis biotypes to glyphosate and ALS-inhibiting herbicides in Argentina. Agricultural Sciences 6:22-30.

Qasem, J.R. 2013. Herbicide resistant weeds: The technology and weed management. p. 445-471. In Price, A.J., and Kelton, J.A. (eds.) Herbicides-current research and case studies in use. IntechOpen, doi:10.5772/56036.

Quintero-Pertúz, I., Carbonó-Delahoz, E., and Jarma-Orozco, A. 2020. Weeds associated with banana crops in Magdalena Department, Colombia. Planta Daninha 38:e020217466.

Ramírez-Muñoz, F. 2016. Resistencia al glifosato en biotipos de zacate cabezón (Paspalum paniculatum L.) de la Región del Caribe de Costa Rica. UNICIENCIA 30(2):75-85.

Ritz, C., Baty, F., Streibig, J.C., and Gerhard, D. 2015. Dose-response analysis using R. PLOS ONE 10(12):e01460211.

Sammons, R.D., and Gaines, T.A. 2014. Glyphosate resistance: state of knowledge. Pest Management Science 70:1367-1377. doi:10.1002/ps.3743.

Sipos, M., and Trif, A. 2009. Anatomy of the vegetative organs at Syngonium podophyllum Schott. Analele Universitatii din Oradea, Fascicula Biologie 16(2):129-134.

Werth, J., Boucher, L., Thornby, D., Walker, S., and Charles, G. 2013. Changes in weed species since the introduction of glyphosate-resistant cotton. Crop Pasture Science 64:791-798.

Zabala, D., Carranza, N., Darghan, A., and Plaza, G. 2019. Spatial distribution of multiple herbicide resistance in Echinochloa colona (L.) Link. Chilean Journal of Agricultural Research 79:576-585.

Zimdahl, R. 2018. Weed ecology. p. 123-178. In Zimdahl, R. (ed.) Fundamentals of weed science. $5^{\text {th }}$ ed. Elsevier Inc., London, UK. 